\title{
INFRASTRUKTUR INFORMASI FILMLESS RADIOLOGY
}

\author{
Romeo $^{1)}$, Febriliyan Samopa ${ }^{2)}$ \\ ${ }^{1}$ Research and Development Department, PT. Medixsoft \\ Jalan Siwalankerto Timur 1/116, Surabaya, 60236 \\ Telp: (031) 8417117, Fax: (031) 8416688 \\ ${ }^{2}$ Jurusan Sistem Informasi, Fakultas Teknologi Informasi, Institut Teknologi Sepuluh Nopember \\ Kampus Keputih, Sukolio Surabaya 60111 \\ Telp: (031) 5999944, Fax: (031) 5964965 \\ E-mail: romeo@medixsoft.co.id
}

\begin{abstract}
Radiology is widely known to be associated with films. However, current imaging modality technology has been able to deliver clinical images in digital format to replace films in radiology practices. This technology brings advance in medical environment as clinical images now can be treated as other digital data. This research is based on study case of radiology department at one of private hospital in Surabaya. It presents an information infrastructure of filmless radiology design to support optimised radiology workflow and integrates it with existing information systems. Information infrastructure filmless radiology is referred to Corporate Infrastructure model, which consists of three main subsystems: picture archiving and communication system (PACS), radiology information system (RIS) and Teleradiology. Additionally, this design also considers one outer radiology area: hospital information system (HIS) with PACS as workflow controller.
\end{abstract}

\section{Abstrak}

Menurut pandangan klasik, radiologi dianggap tidak dapat dipisahkan dari peran film. Namun seiring dengan perkembangan teknologi modalitas pencitraan yang mampu menghasilkan gambar klinis dalam format digital, maka peran film dalam praktik radiologi dapat dihilangkan dan peran data digital di lingkungan medis dapat dioptimalkan. Penelitian dilakukan melalui studi kasus pada instalasi radiologi di salah satu rumah sakit swasta di Surabaya dan bertujuan untuk mendesain infrastruktur informasi filmless radiology untuk mengoptimalkan alur kerja radiologi dan mengintegrasikannya dengan sistem informasi rumah sakit yang ada. Infrastruktur filmless radiology yang dikembangkan mengacu pada model Corporate Infrastructure, melibatkan 3 sub-sistem utama dalam alur kerja radiologi, yaitu: picture archiving and communication system (PACS), radiology information systems (RIS) dan teleradiologi, serta melibatkan satu sistem diluar area radiologi yaitu hospital information system (HIS) dengan PACS sebagai pengendali alur kerja.

Kata kunci: infrastruktur, radiologi.

\section{PENDAHULUAN}

Radiologi memberi kemampuan untuk melihat anatomi dan pathologi manusia melalui deteksi sinyal dan generasi citra, pada radiologi konvensional hal ini dilakukan dengan pembacaan citra medis melalui media film oleh dokter ahli radiologi (radiologis). Seiring dengan perkembangan teknologi, pada praktik radiologi modern mulai dikenal Picture Archiving and Communication System (PACS) atau juga biasa dikenal dengan Image Management and Communication System (IMACS) dan Radiology Information System (RIS) yang adalah sistem informasi utama pada instalasi radiologi modern saat ini sebagaimana diamanatkan oleh Keputusan Menteri kesehatan Republik Indonesia No. 1014/MENKES/SK/XI /2008 tentang Standar Pelayanan Radiologi Diagnostik yang menyebut- kan bahwa rumah sakit kelas A atau setara harus memenuhi kelengkapan alat dan jumlah yang salah satunya adalah sistem penyimpanan dan transmisi citra secara elektronik atau PACS.

PACS adalah sebuah model pencitraan digital dan filmless yang meliputi proses akuisisi, penyimpanan, komunikasi, pengambilan, pemrosesan, pendistribusian, dan penampilan citra medis yang terintegrasi dengan berbagai jaringan digital dan terkomputerisasi.Sedangkan RIS adalah sebuah sistem yang mengelola arus informasi pemeriksaan dari proses registrasi, pemesanan, penjadwalan, dan akuisisi gambar sampai interpretasi, komunikasi hasil, dan penagihan (Smith, 2005 dan Huang, 2004). Konsep utama dari PACS yang terintegrasi RIS adalah digitalized dan filmless yang berarti sistem ini menggantikan hard-copy based 
radiology. Praktik radiologi tanpa menggunakan film disebut filmless radiology atau filmless radiography, pada skala yang lebih besar rumah sakit yang telah menggunakan PACS diseluruh bagian nya disebut filmless hospital. Penelitian yang dilakukan bertujuan untuk mendesain sebuah infrastruktur informasi filmless radiology yang mampu menjalankan alur keja radiologi secara optimal dan terintegrasi dengan sistem informasi rumah sakit yang ada. Rancangan infrastruktur informasi filmless radiology ini mencakup desain PACS, RIS dan Telaradiologi, serta integrasi dengan Hospital Information Systems (HIS) dan modilitas pencitraan medis dengan memperhatikan pemenuhan terhadap persyaratan, regulasi dan perundang-undangan yang berlaku di Indonesia.

\section{METODOLOGI}

Penelitian yang dilakukan dengan pendekatan studi kasus menggunakan metode kualitatif. Brikut ini adalah tahapan-tahapan yang dilakukan selama penelitian. Detail proses selama penelitian di ilustrasikan pada gambar 1, alur proses penelitian.

- Mendesain studi kasus untuk merencanakan dan menetapkan tujuan penelitian.

- Persiapan pengumpulan data untuk nenetapkan prosedur dan protokol pengumpulan data.

- Melakukan pengumpulan data dan informasi.

- Analisis data dan informasi.

- Membuat laporan penelitian.

\section{HASIL dan PEMBAHASAN}

Sistem filmless radiology yang akan didesain melibatkan melibatkan 3 sub-sistem utama dalam alur kerja radiologi, yakni; Picture Archiving and Communication Systems (PACS), Radiology Information System (RIS) dan Teleradiology dengan PACS sebagai pengendali alur kerja. Serta melibatkan satu sistem diluar area radiologi yakni sistem informasi rumah sakit atau dikenal dengan HIS.

Pada gambar 2 model arsitektur PACS sebagai pengendali alur kerja radiologi fungsionalitas perantara diintegrasikan ke dalam PACS, sehingga alur kerja akan dikendalikan oleh PACS. RIS dan Teleradiologi beraksi dalam mode pasif sebagai penyedia sumber informasi dan melanjutkan alur kerja utama. Alur kerja mode ini menunjukkan bahwa saat suatu pemeriksaan dipesan, permintaan akan berjalan melalui suatu jalur dari PACS, dan kemudian dikirim ke modalitas untuk menghasilkan daftar kerja. Saat status pemeriksaan berubah (selesai atau batal), perubahan akan dikomunikasikan ke PACS, kemudian ke RIS. Dan saat PACS dan RIS telah bertukar informasi untuk melakukan validasi pemeriksaan, daftar kerja ahli radiologi dimutakhiran. Workstation akan mencari (query) data ke RIS untuk citra terkait, dan proses berlanjut secara normal. Sedangkan pada alur kerja teleradiologi, permintaan terhadap kerja teleradiologi melibatkan PACS untuk mendapatkan, menyediakan, mengirimkan data yang relevan dan citra medis pasien ke server teleradiologi untuk selanjutnya oleh sistem teleradiologi di distribusikan ke pihak yang berkepentingan.

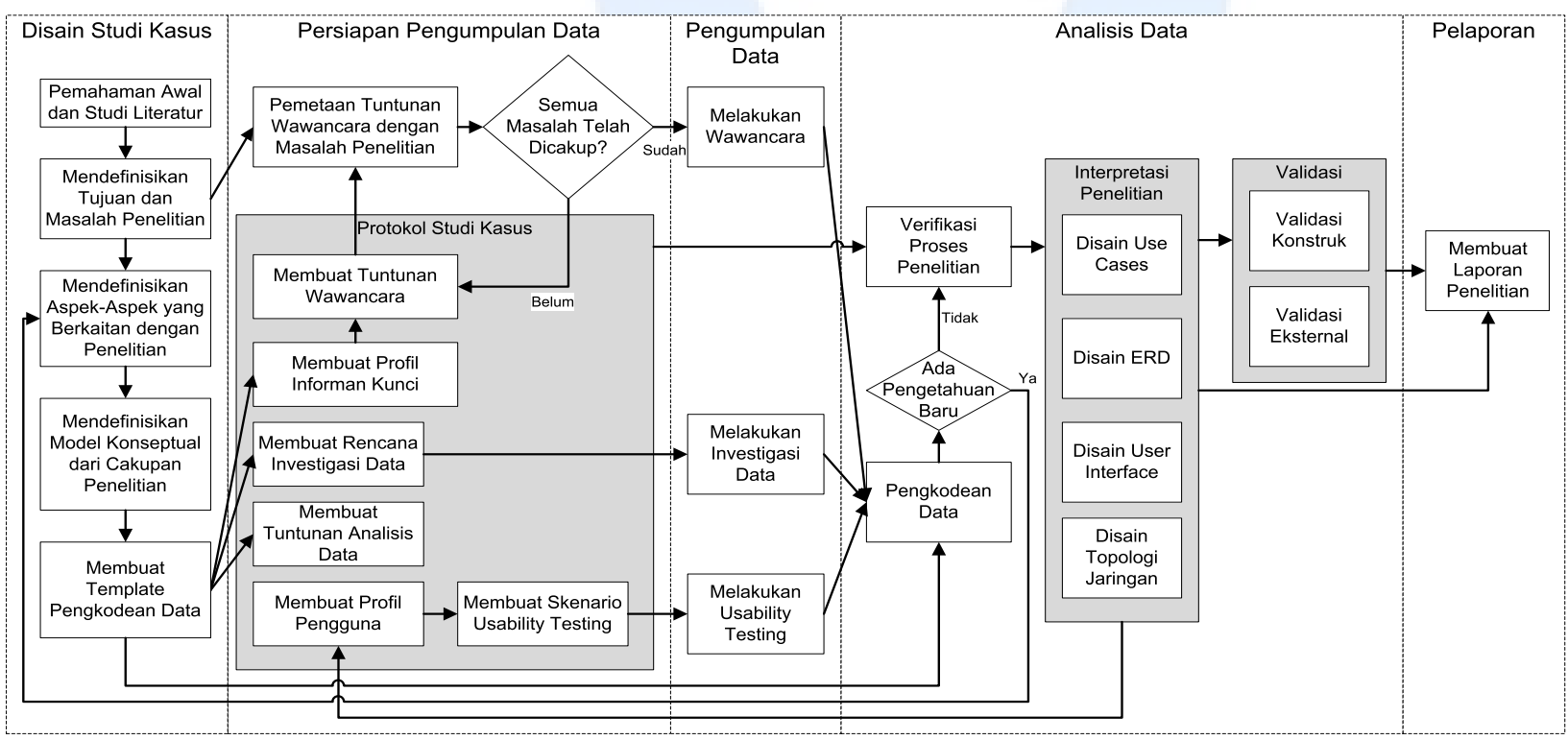

Gambar 1. Alur Proses Penelitian 
Berdasarkan klasifikasi infrastruktur informasi yang dikemukakan oleh Hanseth (Hanseth, 2005), pengembangan desain infrastruktur informasi sistem filmless radiogaphy mengacu pada model Corporate Infrastructure dengan pertimbangan bahwa sistem filmless radiology:

- Dikembangkan dan digunakan secara terbatas oleh user di satu lingkungan tertentu.

- Mengintegrasikan beberapa aplikasi yang sudah ada dan juga memperkenalkan aplikasi baru.

- Keberagaman aplikasi beserta subinfrastruktur, pengguna dan layanan tetapi kesemuanya tidak saling tumpang tindih dan dikelola dengan standar yang jelas.

\section{$\underline{\text { Sub-Sistem PACS }}$}

Sebuah sistem PACS secara sederhana terdiri atas proses akuisisi citra dan data, media penyimpanan dan subsistem penampil yang terintegrasi didalam berbagai macam jaringan digital, sehingga secara umum sebuah PACS terdiri dari sebuah server pusat yang berfungsi sebagai database yang menyimpan citra medis digital, server ini terhubung ke satu atau lebih client melalui jaringan lokal (LAN) atau wide area network (WAN) yang menyediakan dan/atau menggunakan citra medis (Sujadi, 2012).
Proses bisnis PACS jika mengacu pada ErikssonPenker Business Modelling memiliki memiliki komponen-komponen berikut ini.

- Process, menjalankan alur dan fungsi kerja untuk mendapatkan, menyimpan dan mendistribusikan citra medis, termasuk didalamnya menampilkan dan memanipulasi citra medis.

- Goal, menyimpan data dan citra medis pasien, serta menyediakan data dan file citra medis pasien untuk keperluan analisa/ diagnosa.

- Information, data medis pasien dan file citra medis pasien.

- Output, laporan hasil analisa atau diagnosa citra medis pasien.

- Resources, DICOM viewer, serta dukungan sistem dalam mendapatkan dan mentransmisikan citra medis.

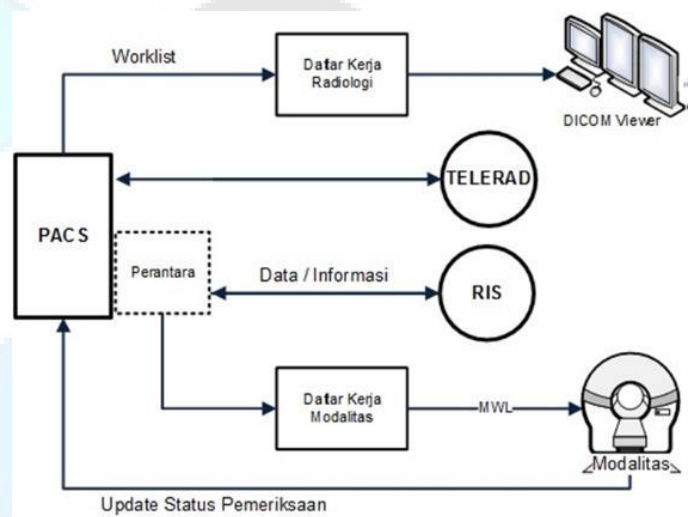

Gambar 2. PACS Sebagai Pengendali Alur Kerja Radiologi

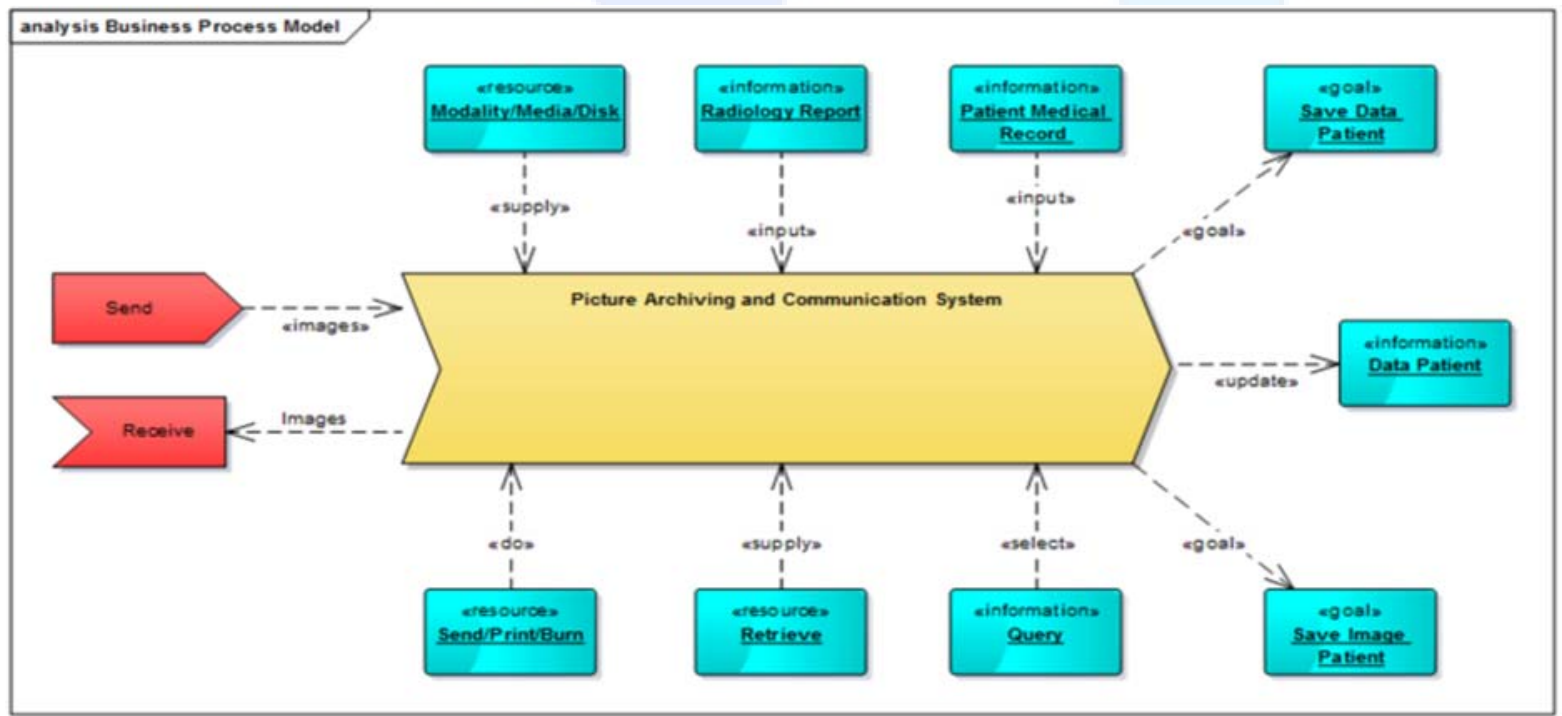

Gambar 3. Diagram Proses Bisnis PAC 


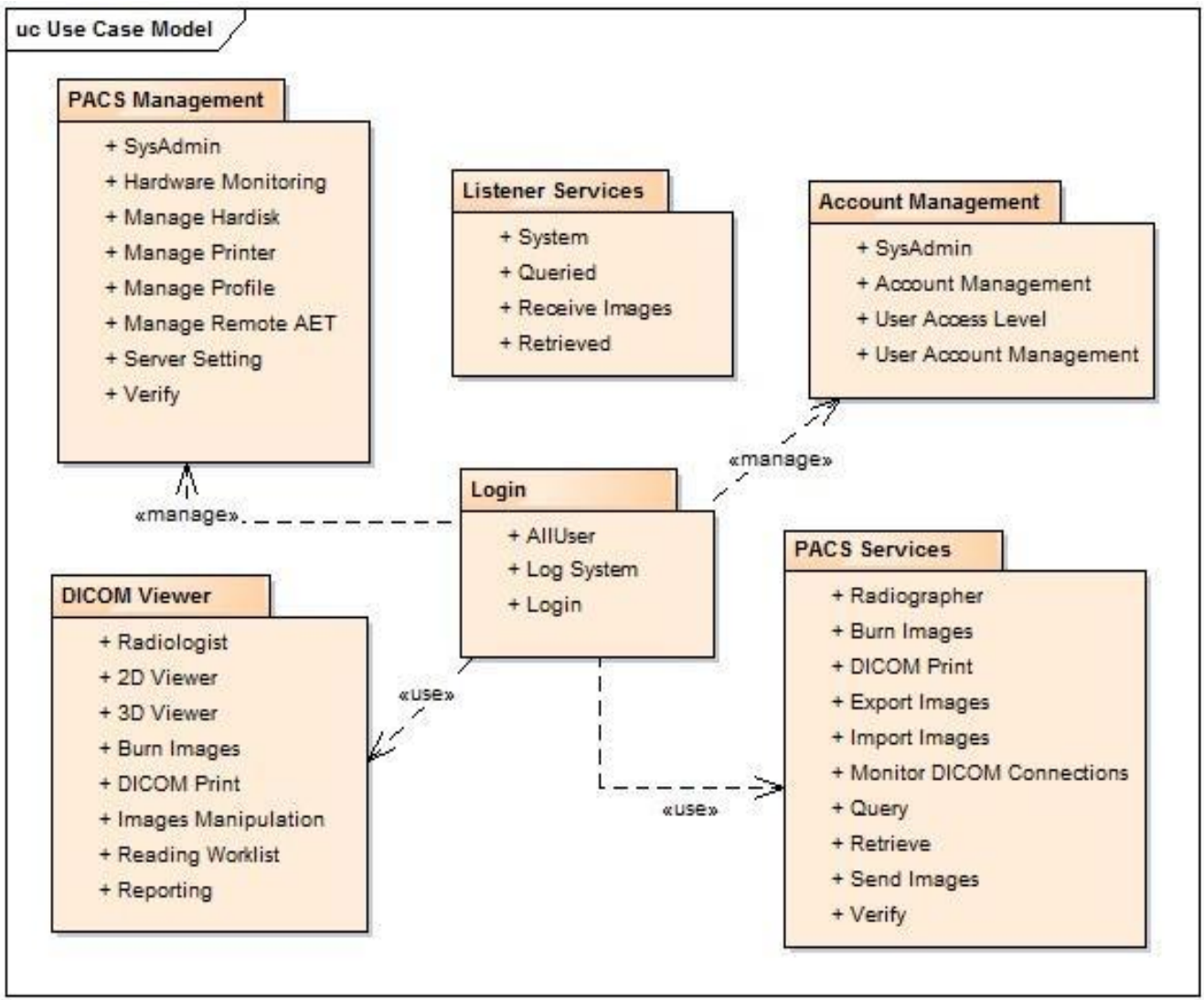

Gambar 4. Daftar Use Case PACS

Secara umum use case model pada sistem PACS memiliki lima proses utama yang dijalankan, yakni; Login, Account Management, PACS Management, DICOM Services dan DICOM Viewer. Sedangkan user/aktor yang terlibat pada sub-sistem PACS antara lain: SysAdmin, Radiographer, Radiologist, dan System Services. Detail daftar use case pada Sub-Sistem PACS di ilustrasikan seperti pada gambar 4. Dalam implementasinya, PACS berfungsi sebagai sentral dari penyimpanan data citra medis pasien di rumah sakit. Secara umum sebuah sistem PACS terbentuk dari beberapa sub-bagian yakni: Client, Modality, Interface, dan Server.

1) Client, adalah entitas yang membutuhkan dukungan masukan dan data dari PACS Server secara langsung. Tanpa adanya masukan data citra medis pasien dan atau informasi yang menyertai dari data citra medis pasien tersebut, sub sistem client ini tidak dapat berjalan dengan baik. Sub sistem client ini mencakup dan tidak terbatas kepada Display Workstation, Film Printer Manager dan Administration Tool.
2) Modality, adalah perangkat untuk melakukan pemeriksaan dan memberikan hasil keluaran yang digunakan dan diarsipkan oleh PACS Server. Tanpa adanya Modalitas ini maka PACS tidak dapat berfungsi dengan baik karena tidak ada pihak yang memberikan citra medis untuk diarsipkan.

3) Interface, modalitas memberikan data citra medis kepada PACS dengan perantara DICOM Gateway (bisa berupa DICOM Listener), Video Acquisition Workstation. Jika pada rumah sakit terdapat modalitas yang masih menghasilkan keluaran berupa film (modalitas analog) maka dibutuhkan sebuah perangkat Film Scanner atau Film Digitizers. Ketiga hal tersebut membentuk sub sistem interfaces, yang juga berperan untuk mengubah/menerjemahkan data dari dua standar yang berbeda.

4) Server, merupakan bagian utama dari sebuah sistem PACS yang terdiri atas PACS controller dan Database Archiving System. PACS controller berfungsi untuk mengendalikan semua transaksi yang ada di dalam sistem, sedangkan Database Archiving System memastikan semua citra medis tersimpan dengan baik dan tersedia jika dibutuhkan (dapat dengan mudah diambil dengan menggunakan berbagai kriteria). 

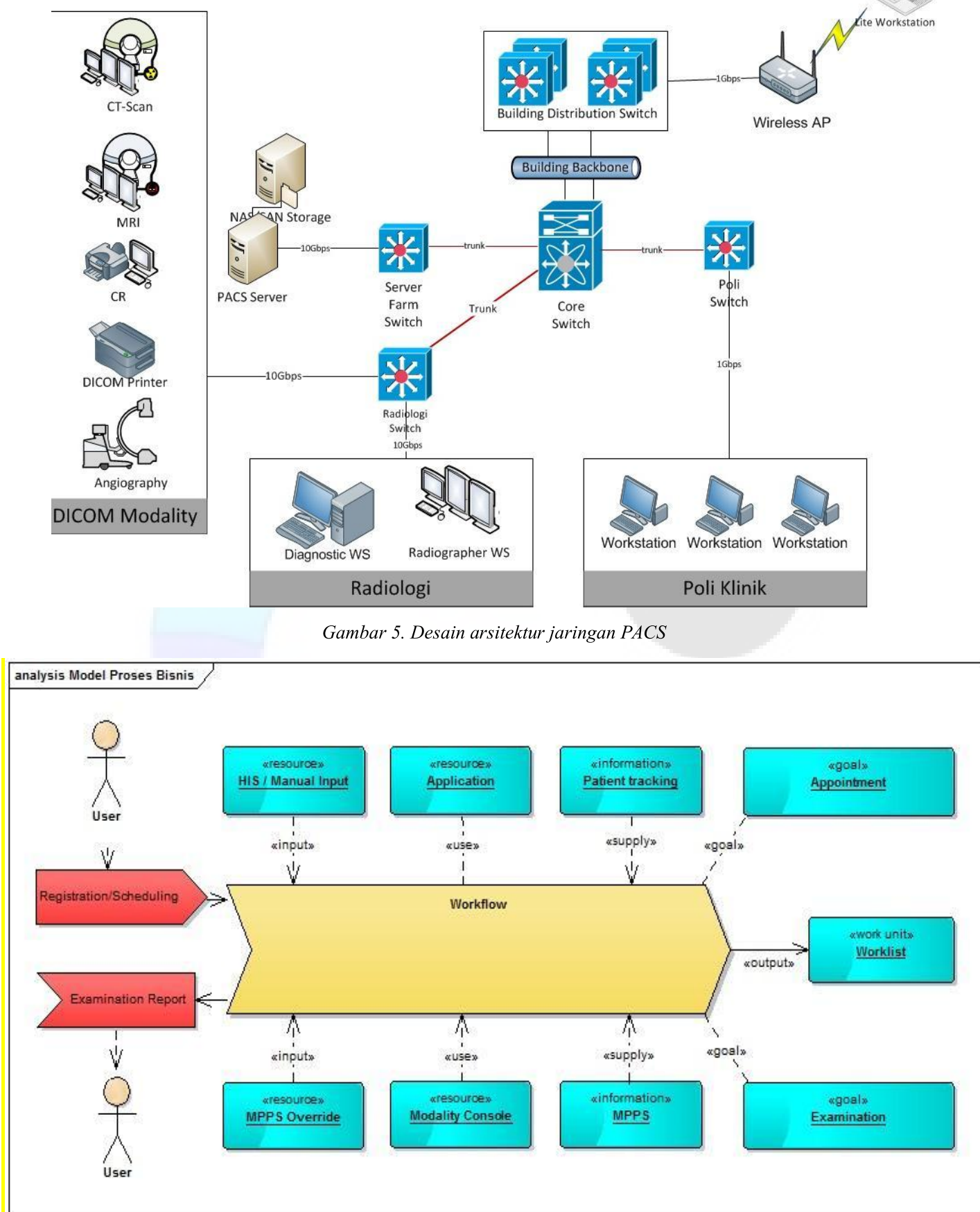

Gambar 6. Diagram Proses Bisnis RIS

\subsubsection{Sub-Sistem RIS}

Radiology Information System (RIS) adalah sebuah sistem komputer yang dirancang untuk mendukung alur kerja dan analisis pada departemen radiologi. RIS juga merupakan tempat penyimpanan data dan informasi pasien, serta memberikan kontribusi terhadap electronic medical record (EMR), (The Royal College of Radiologists, 2008).
Berdasarkan panduan pengembangan teknologi informasi di bidang radiologi yang dikeluarkan oleh The Royal College of Radiologist tentang Radiology Information System (The Royal College of Radiologist, 2008), jika digambarkan menggunakan Eriksson-Penker Business ModellingRIS memiliki memiliki komponenkomponen seperti pada gambar 6 .

- Process, mengelola pendaftaran dan penjadwalan kerja radiologi.

- Goal, melakukan penjadwalan pemeriksaan radiologi. 
- Information, data rekam medis pasien dari patient tracking dan prosedur kerja radiologi.

- Output, daftar kerja radiologi dan laporan hasil pemeriksaan radiologi.

- Resources, data pasien dari HIS atau manual input, standar komunikasi HL7 untuk memungkinkan sistem berkomunikasi dengan modalitas.

Secara umum use case model pada RIS memiliki lima proses utama yang dijalankan, yakni; Login, Account Management, Patient Registration, Scheduling, Billing dan Reporting. Serta memiliki dua aktor yakni SysAdmin dan Admin RIS. Detail daftar use case pada Sub-Sistem RIS di ilustrasikan seperti pada gambar 7. Seperti pada model sistem informasi lain yang berbasis client server, sub-sistem RIS memiliki dua komponen utama yakni pada sisi client (front end) yang menjalankan fungsi menerima masukan dari user atau sistem lain dan komponen server (back end) yang memproses masukan untuk selanjutnya di didistribusikan atau di eksekusi lebih lanjut.
Sub-sistem RIS menjadi lebih sederhana jika diimplementasikan bersamaan dengan PACS karena beberapa fungsi dalam alur kerja radiologi bisa didukung oleh PACS. RIS secara keseluruhan dikelola oleh sebuah server RIS yang independen, yang berfungsi untuk memproses masukan, menyimpan dan mendistribusikan hasil keluaran dari sistem RIS ermasuk juga melayani model pertukaran data dan informasi dari sub-sistem lain seperti HIS.

Aplikasi RIS Client di install pada workstation di front office instalasi radiologi, staff admin menggunakan aplikasi untuk melakukan pendaftaran dan penjadwalan pasien. Aplikasi juga terinstall di workstation radiografer untuk melakukan screening histori pasien dan update status pemeriksaan.

\subsubsection{Sub-Sistem Teleradiologi}

Secara sederhana teleradiologi berarti gambar radiologi dikirim dari lokasi pemeriksaan ke sebuah lokasi lain dimana seorang radiologis (dokter ahli radiologi) akan membuat analisa radiologi, selanjutnya hasil analisa radiologi ini akan dikirim kembali untuk dijadikan bahan rujukan bagi dokter yang menangani pasien.

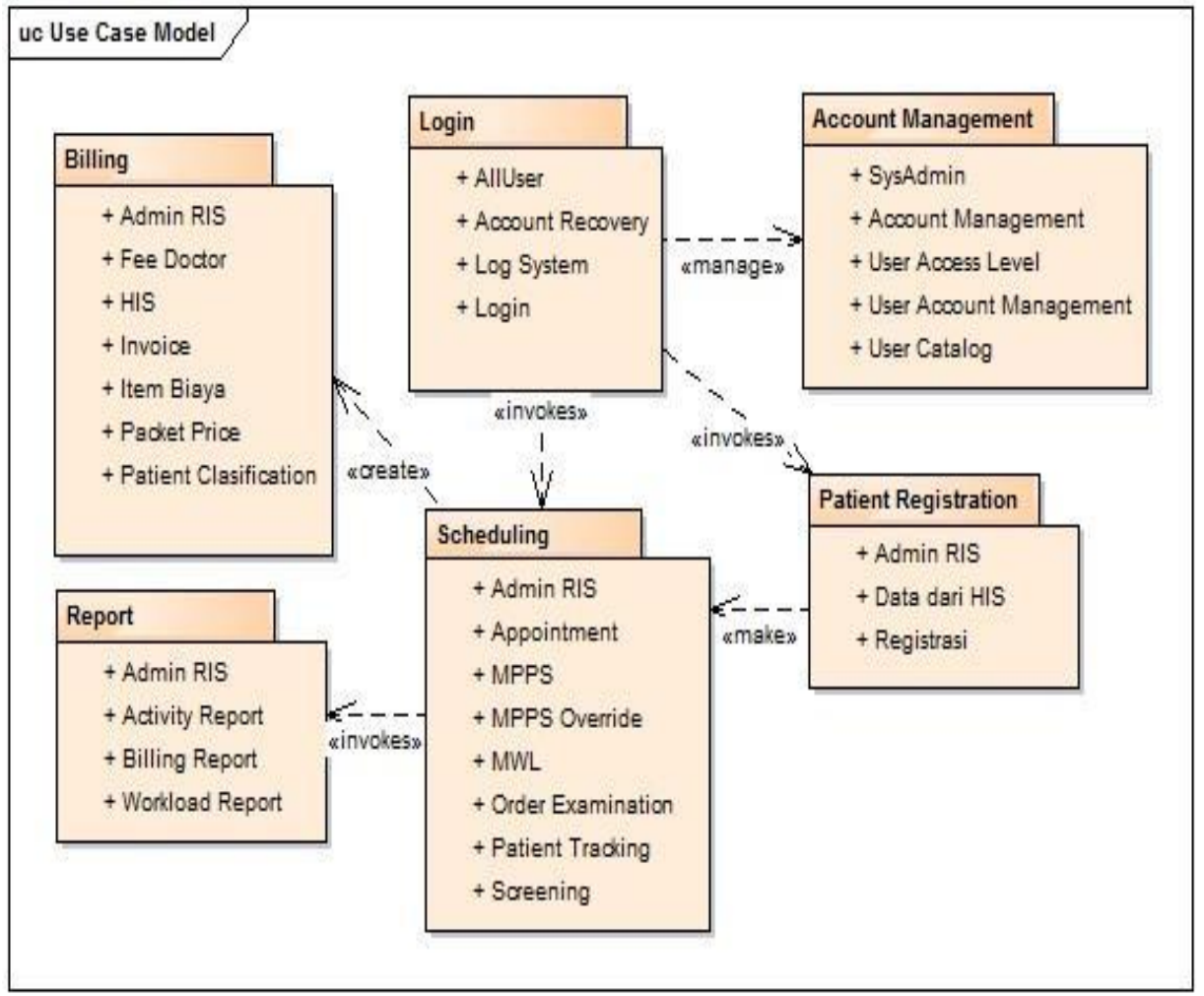

Gambar 7. Daftar Use Case RIS 


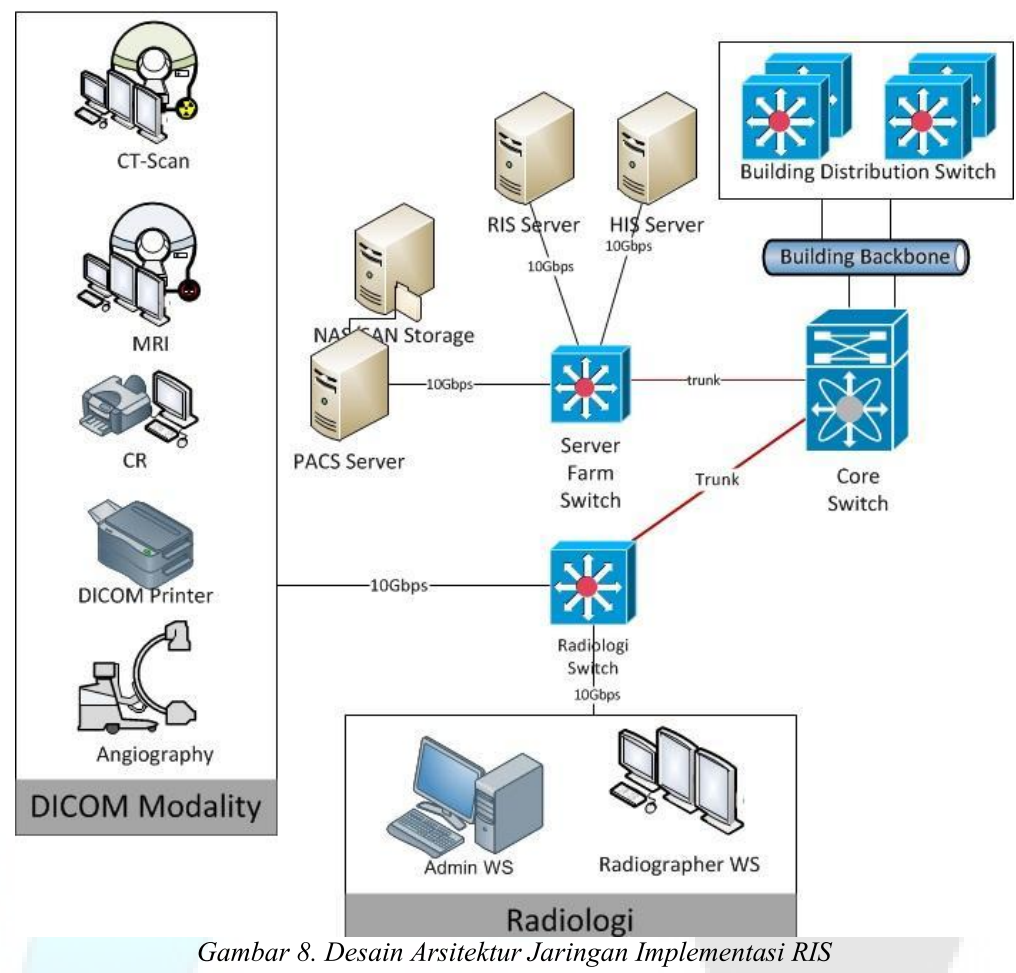

Proses yang terjadi pada model teleradiologi terdiri dari tiga proses utama, yaitu; akusisisi citra medis, transmisi citra medis, dan menampilkan citra medis. Pada implementasinya citra medis pasien di endcoded dalam format digital pada perangkat pengirim, dikirim melalui jaringan transmisi, dan diterima, dilihat, dianalisa dan juga mungkin untuk di simpan pada perangkat penerima.

Gambar 9 menjelaskan proses bisnis teleradiologi secara umum beserta komponen-komponen yang terlibat dalam sebuah alur kerja teleradiologi, mengacu pada pemodelan bisnis ErikssonPenker (Sujadi, 2012). Aktor utama yang terlibat dalam sebuah alur kerja teleradiologi adalah radiografer yang berperan pada proses pengiriman sebuah citra medis dan radiologis yang bertugas untuk melakukan analisa citra medis dan membuat laporan radiologi.
Proses bisnis teleradiologi jika mengacu pada Eriksson-Penker Business Modelling memiliki memiliki komponen-komponen berikut ini.

- Process, menjalankan alur dan fungsi kerja radiologi secara jarak jauh (teleradiologi).

- Goal, Bisa mengirimkan dan mendapatkan file citra medis pasien untuk dilakukan analisa/diagnosa.

- Information, adanya katalog (katalog layanan dan katalog radiologis) dan worklist radiologi.

- Output, laporan hasil diagnosa atau analisa radiologi pasien yang telah dilakukan.

- Resources, aplikasi untuk menjalankan alur kerja teleradiologi, serta dukungan kompatibilitas sistem dalam mendapatkan file/data medis.

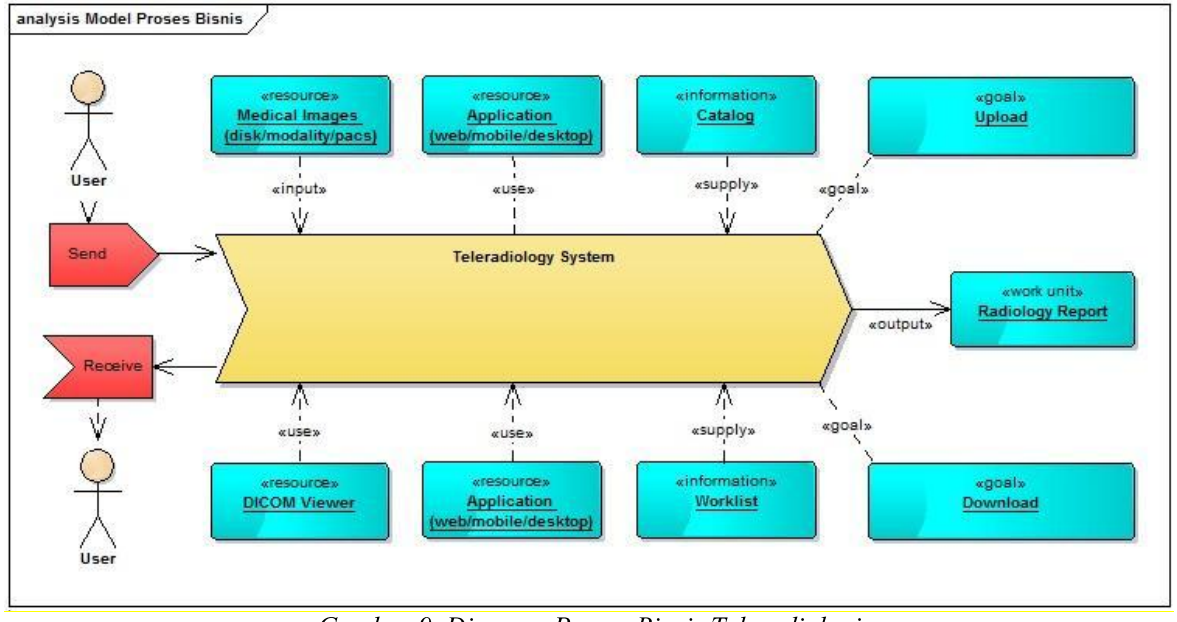

Gambar 9. Diagram Proses Bisnis Teleradiologi 


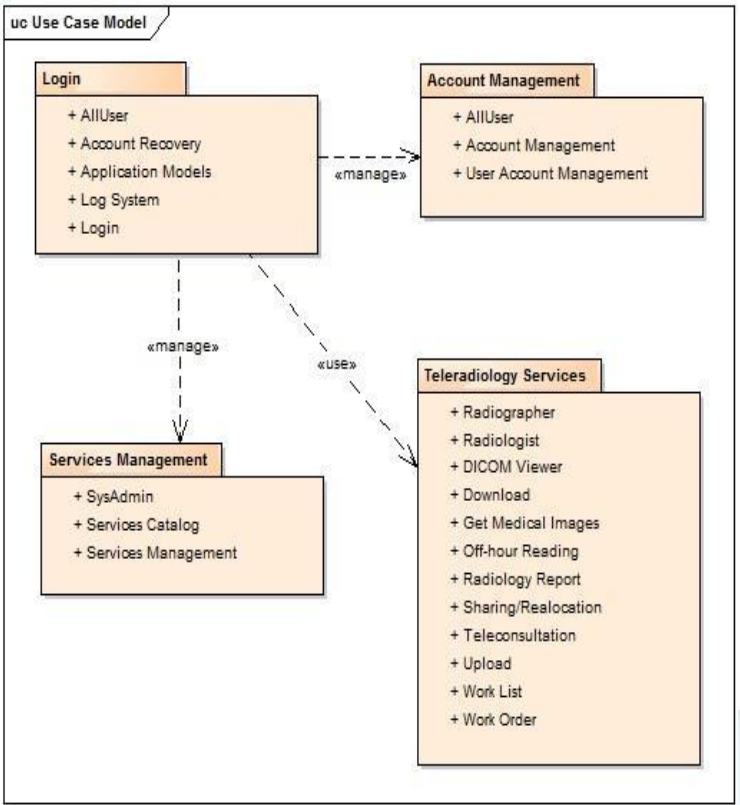

Gambar 10. Daftar Use Case Teleradiologi

Secara umum use case model pada sistem teleradiologi memiliki empat proses utama, yakni; Login, Account Management, Services Management dan Teleradiology Services dan melibatkan tiga user sebagai aktor. Proses utama pada sistem teleradiologi adalah melakukan transmisi data dan citra medis pasien dari satu lokasi ke lokasi lain dimana dokter ahli radiologi berada. Jalur komunikasi data yang akan digunakan adalah jaringan internet, secara lebih spesifik sistem teleradiologi yang didesain dikembangkan dengan menggunakan konsep cloud computing dengan model layanan Data as a Services (DaaS).

Pemilihan cloud computing berbasis Data as a Services untuk sistem teleradiologi didasarkan atas pertimbangan bahwa kebutuhan proses reviewing data citra medis membutuhkan alokasi computational resoures yang cukup besar sehingga akan sulit mengaplikasikan sistem teleradiologi melalui aplikasi berbasis web dengan web server atau cloud computing dengan model Software as a Services (SaaS) seperti yang lazim digunakan (Ramadhan, 2014).

\subsection{Integrasi}

Seperti telah disampaikan didepan bahwa sistem filmless radiology yang didesain kali ini melibatkan tiga komponen utama (sub-sistem) dalam departemen radiologi yakni; PACS, RIS dan Teleradiologi serta satu sistem utama di rumah sakit yaitu HIS. Proses integrasi yang akan dilakukan dari masing-masing sub-sistem seperti ditunjukkan pada gambar 12.

I. Modalitas terintegrasi dengan PACS,

II. Modalitas yang terintegrasi dengan PACS, di integrasikan dengan RIS,

III. Modalitas yang terintegrasi dengan PACS dan RIS, di integrasikan dengan Teleradiologi,

IV. Modalitas yang terintegrasi dengan PACS, RIS dan Teleradiologi, di integrasikan dengan HIS.

\section{Integrasi Aplikasi}

Konsep integrasi dari masing-masing sub-sistem untuk membangun sebuah infrastruktur informasi filmless radiology mengacu pada model Integrated Infrastructure Information Reference Model(III-RM) yang merupakan bagian dari TOGAF TRM (The TOGAF Technical Reference Model). III-RM membantu merancang infrastruktur informasi terintegrasi dengan menghilangkan batasan alur informasi (enable Boundaryless Information Flow) untuk dapat menyediakan: informasi yang terintegrasi, dan akses yangterintegrasi dengan informasi (The Open Group, 2011).

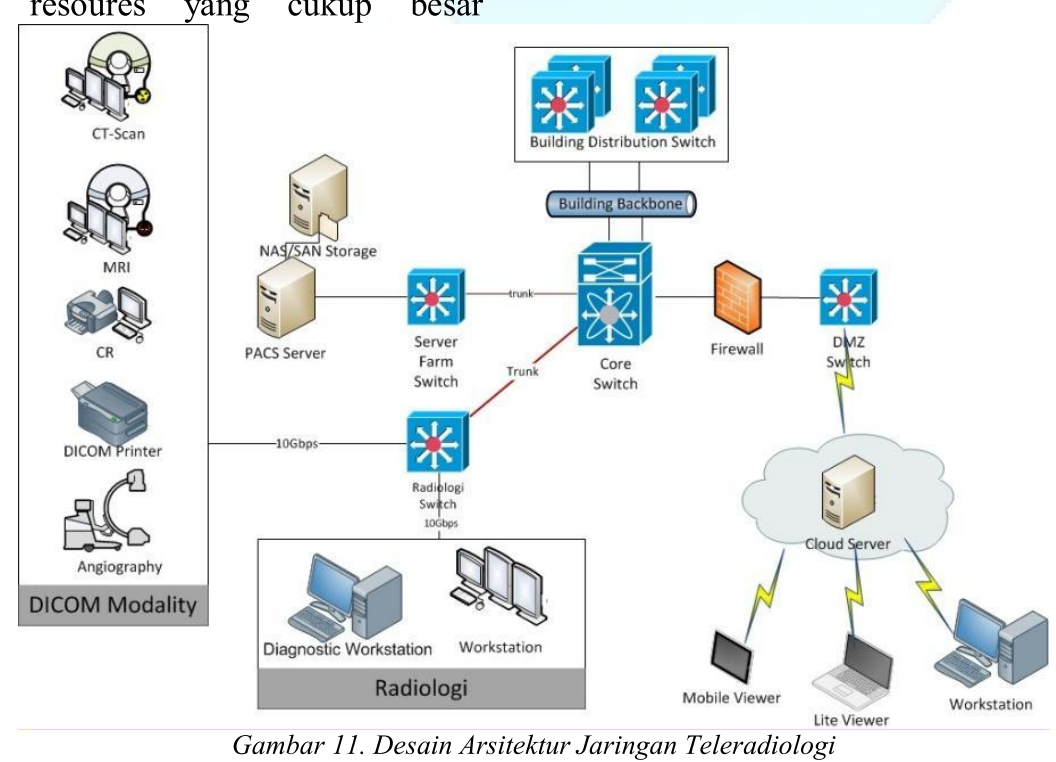


I

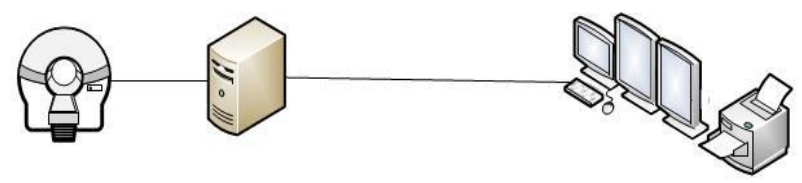

II

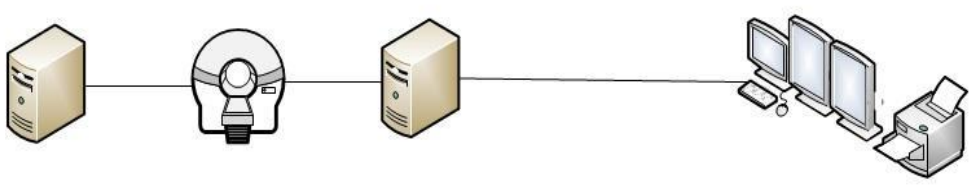

III

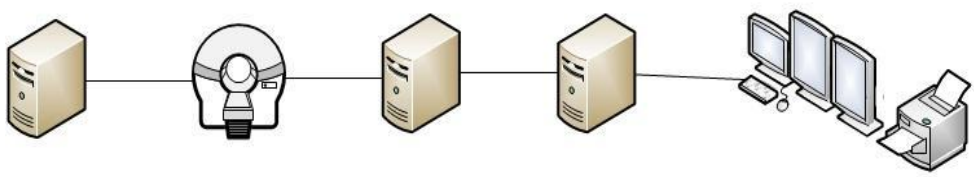

IV

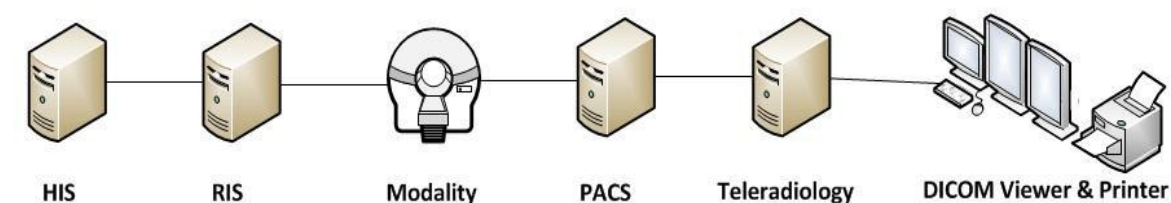

Gambar 12. Proses Integrasi Komponen Filmless Radiology

Lebih lanjut proses integrasi infrastruktur informasi berdasarkan III-RM dikembangkan ke dalam High-Level View, dimana akan diberikan tampilan tingkat ringgi dari III-RM termasuk didalamnya derivasi, grafis dan komponen model. Gambar 14 mengilustrasikan III-RM High Level View sistem filmless radiology.

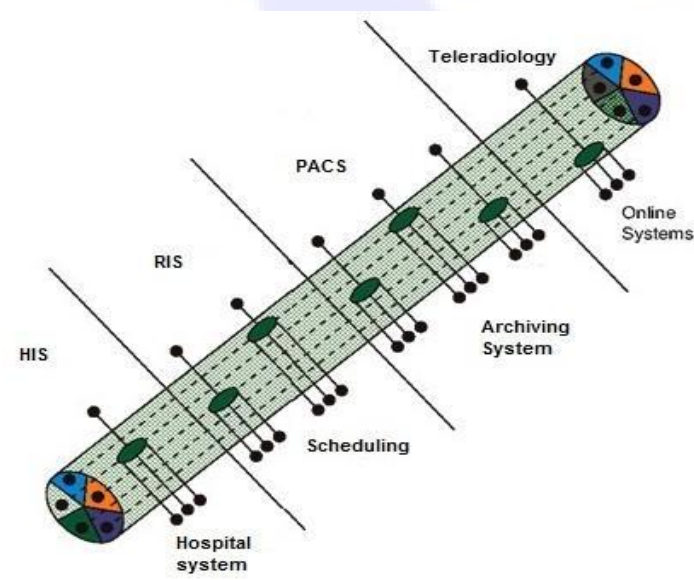

Gambar 13. Pendekatan Boundaryless Information Flow Pada Sistem Filmless Radiology Berdasarkan III-RM

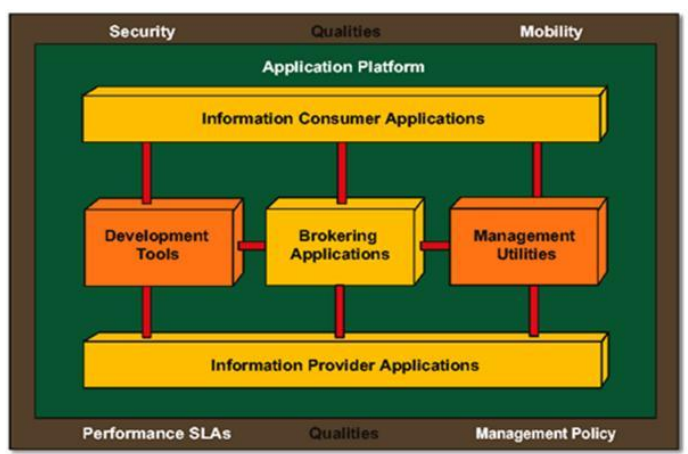

Gambar 14. III-RM High level view graphic (The Open Group, 2011)
Berdasarkan III-RM High Level View Graphic untuk dapat mengintegrasikan infrastruktur informasi yang tersedia sehingga menjadi sebuah sistem yang boundaryless, dibutuhkan Brokering Application atau komponen penghubung (broker) yang mengelola permintaan sehingga memungkinkan sub-sistem untuk saling terhubung, berbagi dan saling mendukung. Komunikasi antar sistem informasi di dunia kesehatan saat ini harus menjadi perhatian yang utama untuk para penyedia layanan medis (Westbrook $\mathrm{dkk}, 2008$ ). Begitu juga halnya yang terjadi pada proses integrasi beberapa sub-sistem yang membangun sistem filmless radiology. Pada sistem filmless radiology yang didesain juga memerlukan aplikasi broker untuk memungkinkan terjadinya komunikasi antar sub-sistem dan juga dengan modalitas radiologi. Jenis Brokering Application yang diperlukan didefinisikan disini sebagai; PACS Broker dan HL7 Broker. Secara umum model integrasi sistem filmless radiology digambarkan melalui blok diagram yang melibatkan komponen pembentuk seperti; modalitas, PACS, RIS, Teleradiologi, HIS dan aplikasi broker seperti di ilustrasikan pada gambar 15 .

\section{PACS Broker}

Konsep PACS Broker adalah menjembatani hubungan antara sistem informasi atau aplikasi dengan modalitas radiologi yang memiliki standar komunikasi DICOM sehingga memungkinkan komunikasi dan pertukaran data atau informasi antar keduanya. Pada penelitian ini keberadaan PACS Broker digunakan oleh RIS untuk berkomunikasi dengan modalitas radiologi dengan menggunakan fungsi MWL (Modality Worklist). MWL adalah standar DICOM untuk melakukan komunikasi dan penarikan data pasien ke modality. MWL mencakup beberapa 
Scheduled Procedure Step (SPS) yang berisi data medis pasien (Nama Pasien, Tanggal, Jam, ID, dll). Pada setiap aktivitas pencitraan, modalitas akan memberikan status Complete, In Progress dan Discontinue. Status tersebut berguna untuk melihat proses pengambilan pencitraan yang dilakukan terhadap seorang pasien. Status dari modalitas tersebut dikirim ke RIS melalui Modality Performed Procedure Step (MPPS) (Chang. dkk, 2003). MPPS adalah standart DICOM untuk melakukan komunikasi dan pengiriman status pasien dari modalitas ke sistem diluar (dalam hal ini adalah RIS).

Akan tetapi akan dijumpai beberapa modalitas yang tidak memiliki fungsi MWL dan MPPS. Di modalitas bisa dilakukan input data dengan menggunakan Barcode 2D, Maka pada RIS disediakan fungsi mencetak Barcode 2D sebagai pengganti MWL dan diberikan proses MPPS secara manual.

\section{HL7 Broker}

HL7 Broker adalah salah satu application broker yang dirancang sebagai antar muka sistem rumah sakit. Broker bertugas menerjemahkan setiap data pasien menjadi data HL7 agar bisa dikirim ke sub-sistem yang memakai standard HL7. Fungsi utama dari broker HL7 adalah mengintegrasikan data pasien antar aplikasi seperti HIS, RIS dan PACS (Benson, 2010).

Standard HL7 yang dipakai pada HL7 Broker adalah HL7 Message version 2.5.1 bertipe
ORU^R01 dan $\mathrm{OMI}^{\wedge} \mathrm{O} 23$. Pesan HL7 bertipe ORU^R01 berfungsi mengirim data yang dihasilkan dari pencitraan medis (RIS, PACS) ke HIS. Sedangkan pesan HL7 bertipe $\mathrm{OMI}^{\wedge} \mathrm{O} 23$ untuk komunikasi antara sistem informasi yang terlibat dalam pemenuhan kebutuhan akan pencitraan (ANSI, 2007) yang dalam hal ini adalah antara RIS dan HIS.

Proses integrasi informasi antara HIS dengan RIS digambarkan dengan blok diagram seperti pada gambar 15, konsep kerja HL7 Broker adalah HIS mengirimkan medical imaging order ke RIS, HL7 Broker menerima kiriman dari HIS, lalu meng-generate order menjadi HL7 Message $\mathrm{OMI}^{\wedge} \mathrm{O} 23$ dan mengirimkan ke RIS, RIS mengirimkan laporan pembacaan melalui HL7 Broker, HL7 Broker mengeluarkan hasil pembacaan kedalam HL7 Pesan tipe ORU^R01 dan dikirimkan ke HIS.

\section{Integrasi Teknologi}

Integrasi dari infrastruktur teknologi, dalam hal ini adalah kebutuhan hardware untuk membangun sistem filmless radiology mengacu pada kebutuhan infrastruktur masing-masing sub-sistem yang telah dijelaskan di depan. Desain arsitektur teknologi jaringan filmless radiology seperti diilustrasikan pada gambar 16 . Desain ini mengakomodasi semua kebutuhan dari tiap-tiap sub-sistem baik internal instalasi radiologi maupun dengan sub-sistem eksternal di rumah sakit.

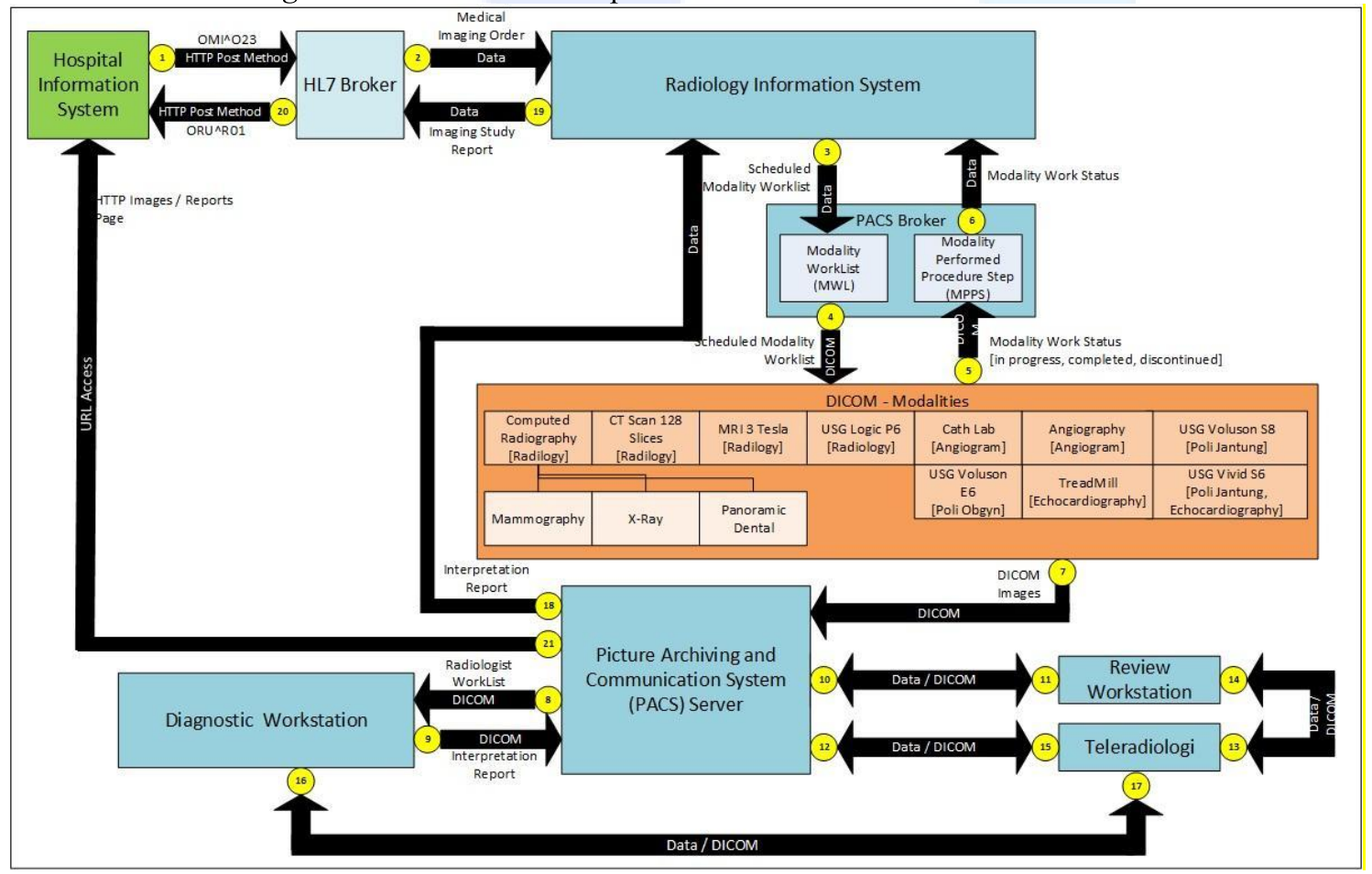

Gambar 15. Blok Diagram Sistem Filmless Radiology 
Sebuah server farm disebut juga computer cluster, yaitu sekelompok server yang ada di suatu lokasi yang sama. Server-server ini dikoneksikan dalam jaringan secara bersama, sehingga memungkinkan bagi mereka untuk memenuhi kebutuhan server yang sulit bahkan tak mungkin dilakukan oleh hanya 1 server. Dengan sebuah server farm, beban kerja didistribusikan diantara komponen-komponen server yang ada, memberikan cara untuk meringankan tugas-tugas komputerisasi berat dan proses komputasi dapat dipercepat.

Pada sistem teleradiologi, untuk memperkecil tingkat resiko terjadinya bahaya ancaman dari luar (internet) bagi keamanan jaringan internal, DMZ switch digunakan untuk memisahkan jaringan internal dengan internet. Modifikasi masih memungkinkan untuk dilakukan khususnya pada infrastruktur server, yakni keberadaan server PACS dan RIS yang mungkin bisa digabungkan fungsinya. Akan tetapi keberadaan server yang independent akan lebih baik.

\subsection{Verifikasi dan Validasi}

Proses verifikasi dan validasi pada desain infrastruktur informasi filmless radiology yang dihasilkan pada peneltian thesis ini menggunakan panduan pengembangan desain infrastruktur informasi yang mengacu pada desain infrastruktur informasi internet (Abbate, 1999). Penggunaan internet sebagai acuan dalam desain pengembangan II didasari bahwa proses pengembangan internet mampu menggambarkan secara konkret bagaimana panduan mengembangkan infrastruktur layanan universal, dan bahwa panduan yang digunakan adalah yang diikuti selama desain internet dari pertama kali dikenalkan hingga sekarang.

Hasil validasi desain infrastruktur informasi filmless radiology pada penelitian ini dirangkum pada tabel 1. Secara umum dapat disimpulkan bahwa proses yang dilakukan dan desain yang dihasilkan mampu memenuhi panduan yang ada karena telah mengikuti sebagian besar dari daftar panduan yang ada.

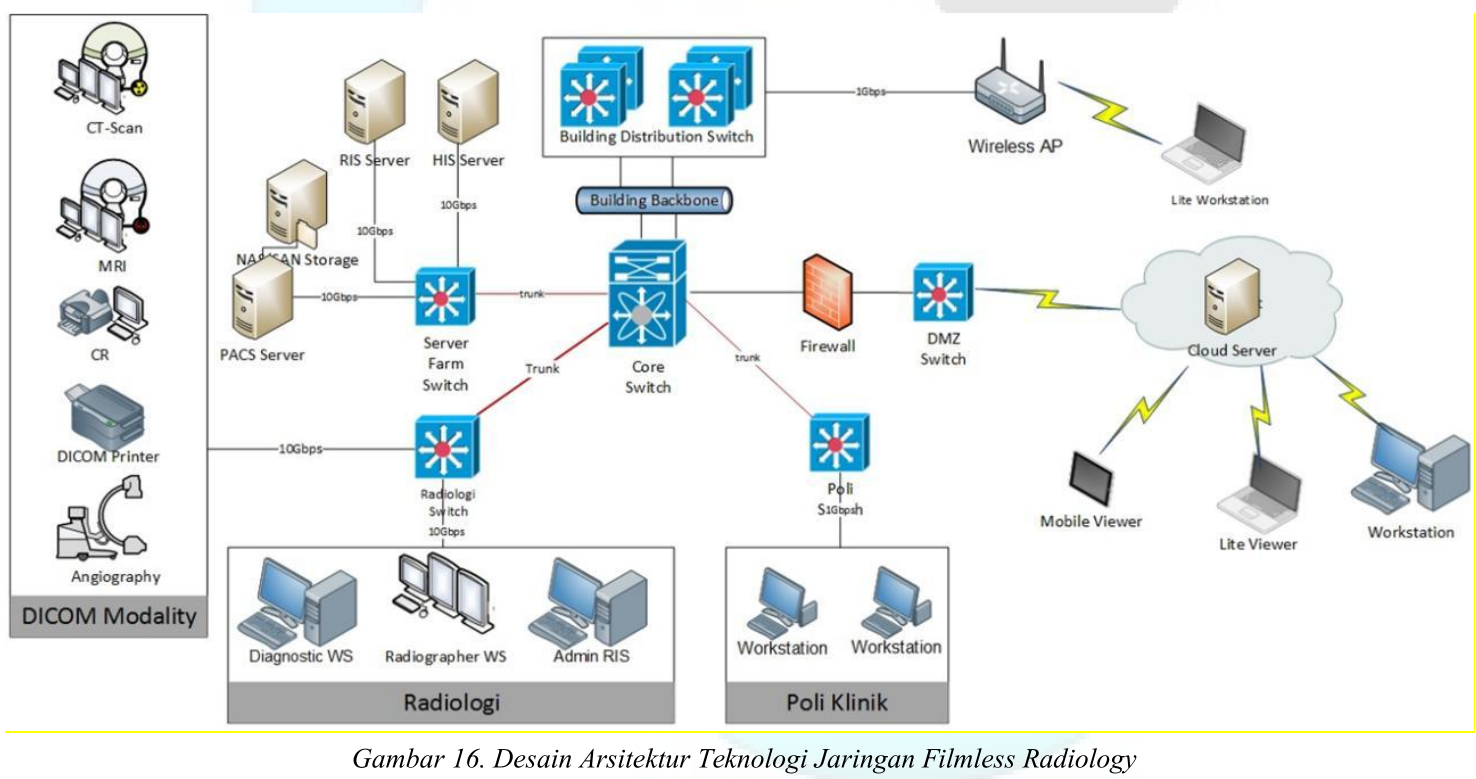

Table 1. Validasi Desain Infrastruktur Filmless Radiology

\begin{tabular}{llll}
\hline \multicolumn{1}{c}{ Design strategy: Build installed base } & \\
\hline \multicolumn{1}{c}{ Petunjuk Desain } & Diikuti & $\begin{array}{c}\text { Tidak } \\
\text { Diikuti }\end{array}$ & \multicolumn{1}{l}{ Komentar } \\
\hline $\begin{array}{l}\text { 1. Target the II for a } \\
\text { small group }\end{array}$ & $\mathrm{X}$ & $\begin{array}{l}\text { Subsistem pertama yang didesain adalah PACS yang hanya } \\
\text { digunakan oleh internal di instalasi radiologi, selanjutnya } \\
\text { dikembangkan subsistem RIS yang memungkinkan berkolaborasi } \\
\text { dengan SI diluar area radiologi. Subsistem teleradiologi } \\
\text { menjadikan sistem filmless radiology bisa diakses dari luar oleh } \\
\text { kelompok user yang lebih besar. }\end{array}$ \\
& & Aplikasi yang dikembangkan semuanya adalah installed base, \\
2. Design early on so & $\mathrm{X}$ & &
\end{tabular}

useful without an

installed base.

3. Make it simple so $\quad \mathrm{X}$

that it is easy to

Sistem dibuat sesimple mungkin dengan tidak mengurangi fungsi

develop and easy to

dalam menjalankan alur kerja radiologi. Beberapa fitur bahkan

learn to use

dijalankan otomatis oleh sistem. 


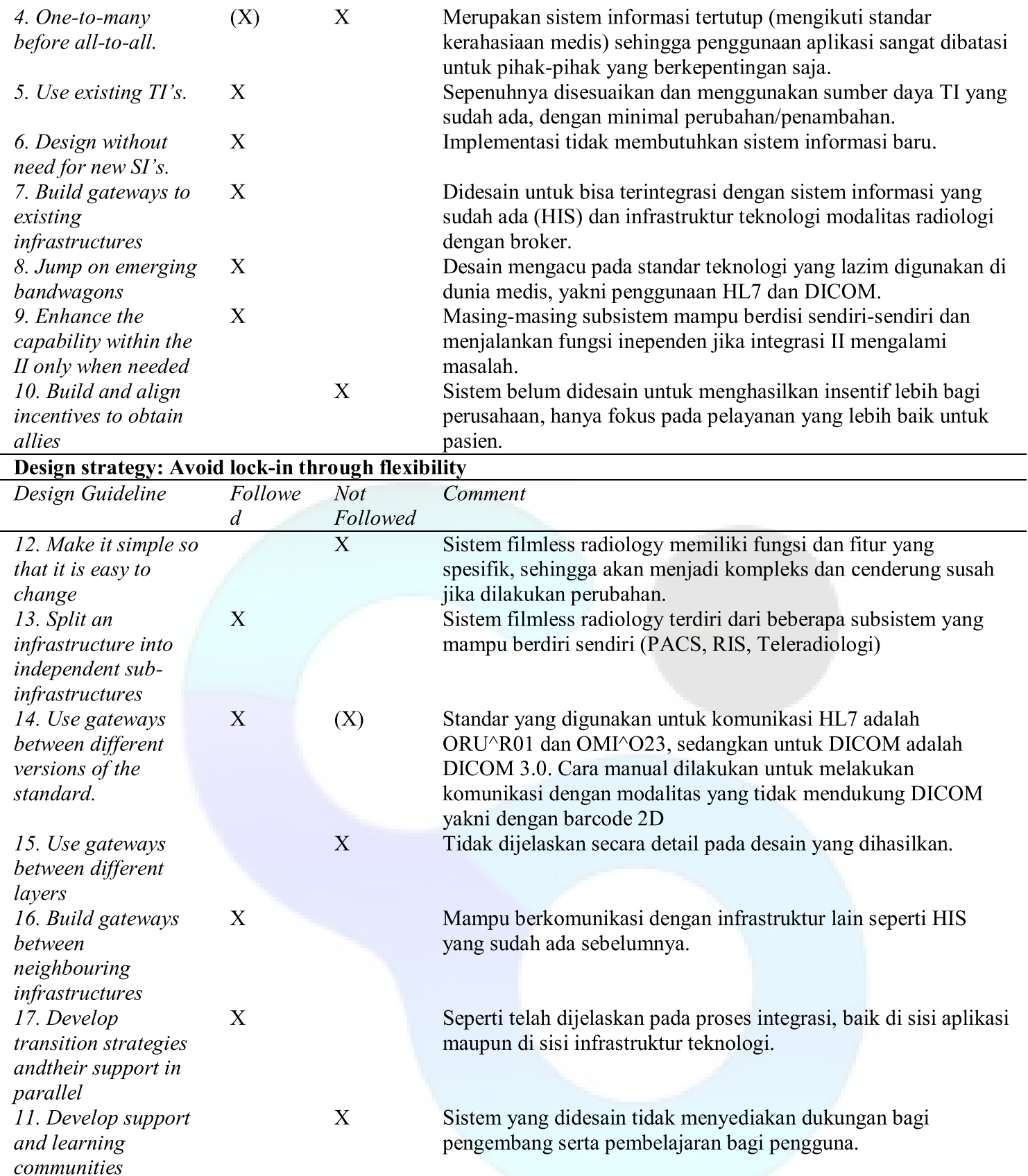

\section{KESIMPULAN dan SARAN}

Berdasarkan hasil dari penelitian, pembahasan dan temuan-temuan yang didapat, berikut ini adalah kesimpulan yang bisa diambil terkait penelitian yang telah dilakukan antara lain. Penggunaan standar medis dalam pengembangan sistem atau aplikasi di bidang medis menjadi satu keharusan untuk dapat menjamin produk sistem telah sesuai dengan syarat dan regulasi yang berlaku baik nasional maupun internasional.Strategi pengembangan sistem filmless radiology dengan PACS sebagai pengendali alur kerja radiologi dipilih karena PACS merupakan sistem inti dan biasanya adalah sistem pertama yang dimiliki pada instalasi radiologi, sedangkan sub-sistem lain seperti RIS dan Teleradiologi merupakan subsistem yang mendukung, dan HIS berada di luar area radiologi. Keberadaan sistem teleradiologi diharapkan mampu menjalankan alur kerja radiologi tanpa terkendala batasan waktu dan ruang, ini mendukung institusi kesehatan dalam memberikan layanan yang lebih baik kepada pasien.

Beberapa saran yang bisa diberikan untuk pengembangan sistem filmless radiology yang lebih optimal dalam memenuhi kebutuhan organisasi serta untuk keperluan penelitian selanjutnya dimasa mendatang mengingat pemeriksaan berbasis citra saat ini sudah tidak didominasi oleh instalasi radiologi, beberapa instalasi seperti cardiology, surgery dan obgyn 
juga menggunakan/melakukan pemeriksaan berbasis citra, sehingga kedepannya sistem filmless radiology didesain untuk bisa digunakan oleh semua instalasi medis yang menggunakan pemeriksaan berbasis citra tanpa terkecuali,keberadaan sistem filmless radiology yang mampu menyimpan data digital citra medis memungkinkan sistem filmless dikembangkan untuk kebutuhan penelitian dan pengembangan medis di institusi rumah sakit berdasarkan database citra medis yang dimiliki, masih berhubungan dengan fungsi penelitian dan pengembangan, sistem teleradiologi dapat di optimalkan untuk menjalankan fungsi pembelajaran dan berbagi pengetahuan dengan melibatkan banyak institusi kesehatan lain.

\section{DAFTAR RUJUKAN}

Abbate, J., 1999. Inventing The Internet, MIT Press, Cambridge.

ANSI, 2007.Health Level Seven Standard Version 2.5.1 - An Application Protocol for Electronic Data Exchange in Healthcare Environments. Washington: American National Standards Institute.

Benson, T., 2010. Principles of Health Interoperability HL7 and SNOMED. Springer: New York.

Hanseth, Ole \& Lyytinen, Kalle, 2005.Theorizing about the Design of Information Infrastructures: Design Kernel Theories and Principles. Sprouts: Working Papers on Information Systems. Sprouts.

Huang, HK., 2004. PACS - Basic Principles and Applications.New York: John Wiley \& Sons.
Menteri Kesehatan Republik Indonesia. Standar Pelayanan Radiologi Diagnostik di Sarana Pelayanan Kesehatan, Keputusan Menteri Kesehatan Republik Indonesia NOMOR 1014/MENKES/SK/XI/2008.

Rahmadhan, Rahmad, 2014. Rancang Bangun Aplikasi Teleradiologi Berbasis Cloud Dengan Prinsip Data as a Services. Tugas Akhir, Surabaya: Institut Bisnis dan Informatika STIKOM Surabaya.

Smith, G., 2005. "Introduction to RIS and PACS". In Dreyer K. J., Mehta A., Thrall J. H. (Eds.), PACS: A Guide to the Digital Revolution, 2nd ed., Springer Verlag.

Sujadi, Agus, 2012.Analisis dan Desain Cloud Computing Teleradiologi. Tesis Magister. Surabaya: Institut Teknologi Sepuluh Nopember.

The Open Group, 2011.TOGAF® Version 9.1. The Open Group Standard.

The Royal College of Radiologist, 2008.Radiology Information Systems. UK: The Royal College of Radiologists.

Westbrook, J.,dkk, 2008. All in a Day's Work: An Abservational Study to Quantify How and With Whom Doctors on Hospital Wards Spend Their Time. Charlotte:MJA.

Chang, Zhanjun, dkk., 2003. Research on the HRPS-based standardised conversion technique of non-DICOM medical image equipments interface. International Journal of Healthcare Technology and Management, 5(6). 